\title{
PENGARUH MODEL PEMBELAJARAN OPEN ENDED BERBASIS PENILAIAN PROYEK TERHADAP KOMPETENSI PENGETAHUAN PPKn SISWA
}

\author{
I K. N. Wiyasa' ${ }^{1}$ A. A. G. Agung ${ }^{2}$, I G. A. A. S. Asri ${ }^{3}$ \\ ${ }^{1,2}{ }^{\prime 3}$ Jurusan Pendidikan Guru Sekolah Dasar \\ Universitas Pendidikan Ganesha \\ Singaraja, Indonesia \\ e-mail: gede.agung@ undiksha.ac.id ${ }^{1}$, \\ igaagungsri.asri@undiksha.ac.id²,ngrh.wiyasa@undiksha.ac.id ${ }^{3}$
}

\begin{abstract}
ABSTRAK
Penelitian ini bertujuan untuk mengetahui perbedaan yang signifikan kompetensi pengetahuan PPKn kelompok siswa yang dibelajarkan dengan model pembelajaran Open Ended berbasis penilaian proyek dengan kelompok siswa dibelajarkan dengan pembelajaran konvensional pada kelas IV SD Gugus I Kecamatan Gianyar Tahun Pelajaran 2017/2018. Penelitian ini merupakan penelitian eksperimen semu dengan rancangan kelompok non-ekuivalen. Populasi pada penelitian ini ialah seluruh siswa kelas IV SD Gugus I Kecamatan Gianyar Tahun Pelajaran 2017/2018 yang berjumlah 343 orang. Penentuan sampel dalam penelitian menggunakan teknik random sampling dengan pengacakan kelas yang sudah ada, kemudian dilakukan pengudian untuk penentuan kelompok eksperimen dan kontrol sehingga kelas IV Melati SD Negeri 2 Gianyar sebanyak 36 siswa sebagai kelompok kelas eksperimen dan kelas IV A SD Negeri 1 Gianyar sebanyak 44 siswa sebagai kelompok kelas kontrol. Data kompetensi pengetahuan PPKn siswa dikumpulkan dengan instrumen tes objektif pilihan ganda biasa sebanyak 30 soal yang sudah divalidasi. Nilai gain skor dinormalisasi kelas IV Melati dibawah rata-rata sebanyak 15 orang dan yang mencapai rata-rata sebanyak 21 orang sedangkan nilai gain skor dinormalisasi kelas IV A yang berada dibawah ratarata sebanyak 21 orang dan yang mencapai rata-rata sebanyak 23 orang. Hasil analisis uji-t menunjukkan nilai $t_{\text {hitung }}=2,494>t_{\text {tabel }}(a=0,05, d k=78)=1,991$ sehingga $H_{0}$ ditolak dan $H_{a}$ diterima. Sesuai dengan hasil tersebut dapat disimpulkan model pembelajaran Open Ended berbasis penilaian proyek berpengaruh terhadap kompetensi pengetahuan PPKn siswa kelas IV SD Gugus I Kecamatan Gianyar Tahun Pelajaran 2017/2018. Untuk peneliti yang memiliki kesamaan variabel, hasil penelitian ini dapat dipergunakan sebagai kajian penelitian relevan.
\end{abstract}

Kata kunci: open ended, penilaian proyek, PPKn

\begin{abstract}
The purpose of this research was to know the significant difference of knowledge competence of PPKn group of students which were taught by Open Ended learning model based on project assessment with group of students taught by conventional learning in fourth grades of SD Gugus I Gianyar Sub District Academic Year 2017/2018. This research was a quasi-experimental study with non-equivalent group design. Population in this research were all fourth graders of SD Gugus I Gianyar Sub District Academic Year 2017/2018 which amounted to 343 people. Determination of the sample in this reseach used random sampling technique with existing class scramble, then to determin of both of experimental and control groups were drawed so the fourth grade Melati SD Negeri 2 Gianyar as 36 students as experimental class and fourth grade A SD Negeri 1 Gianyar as much 44 students as a control class group. The student's knowledge competence data were collected with an ordinary double-choice objective test instrument of 30 validated questions. The gain score normalization value of fourth grades Melati under the average of 15 people
\end{abstract}


and which reached an average of 21 people while the gain score normalization value of fourth grades A which were below the average of 21 people and who reached an average of 23 people. The result of $\mathrm{t}$-test analysis shows $\mathrm{t}_{\text {calculate }}=2,494>\mathrm{t}_{\text {table }}(\mathrm{a}=0,05, \mathrm{dk}=78)=1,991$ so $\mathrm{H}_{0}$ was rejected and $\mathrm{H}_{\mathrm{a}}$ accepted. In accordance with these results can be concluded Open Ended learning model based on project assessment affect the competence of knowledge PPKn fourth graders of SD Gugus I Gianyar Sub District Academic Year 2017/2018. For researchers who have similarities of variables, the results of this research can be used as a relevant research.

Keywords: open ended, project assessment, PPKn

\section{PENDAHULUAN}

Kemampuan sumber daya manusia (SDM) merupakan hal yang penting untuk dikembangkan melalui pendidikan. Pendidikan diartikan sebagai "sebuah proses dengan metode-metode tertentu sehingga orang memeroleh pengetahuan, pemahaman, dan cara bertingkah laku yang sesuai dengan kebutuhan"(Syah, 2010:10). Sedangkan menurut Trianto (2015:1) "Pendidikan adalah salah satu bentuk perwujudan kebudayaan manusia yang dinamis dan sarat perkembangan". Pendidikan yang baik akan mampu menghasilkan SDM berkualitas, mampu bersaing, memiliki budi pekerti luhur, dan dapat mengabdikan diri pada negara.

Proses pendidikan yang bagus berkaitan erat dengan kurikulum sebagai pedoman dalam proses pengembangan pendidikan. Kurikulum merupakan strategi yang disepakati dan dipergunakan sebagai pedoman untuk pelaksanaan pembelajaran. Menurut Undang-Undang RI No. 20 Tahun 2003 Tentang sistem Pendidikan nasional dikatakan bahwa kurikulum adalah seperangkat rencana dan pengaturan mengenai isi, bahan pelajaran serta cara yang digunakan sebagai pedoman penyelenggaraan kegiatan belajar mengajar. Perubahan kurikulum merupakan kebijakan publik melibatkan penggunaan waktu, keahlian, dana, peralatan, dan pengorbanan. Semua hal tersebut dilakukan demi memperoleh yang terbaik, hingga saat ini di Indonesia telah menerapkan Kurikulum 2013 sebagai pedoman pelaksanaan pembelajaran pada pendidikan dasar hingga pendidikan menengah.
Implementasi dari sebuah kurikulum adalah terlaksananya pembelajaran pada tingkat satuan pendidikan. Pembelajaran merupakan "proses komunikasi dua arah, mengajar dilakukan oleh pihak guru sebagai pendidik, sedangkan belajar dilakukan oleh peserta didik atau murid" (Sagala, 2013:61). Pembelajaran kurikulum 2013 menggunakan pendekatan saintifik atau pendekatan berbasis proses keilmuan dengan pembelajaran tematik integratif yang sudah diterapkan di sekolah dasar. Pembelajaran tematik integratif yaitu mengaitkan beberapa kompetensi dasar dari mata pelajaran yang dipadukan kedalam sebuah tema. Beberapa mata pelajaran dipadukan dalam pendekatan saintifik seperti Bahasa Indonesia, PPKn, Matematika, IPA, IPS, Penjaskes, dan SBdP yang dipadukan sedemikian rupa sehingga siswa tidak menyadari sedang mempelajari mata pelajaran tertentu. Hal tersebut dimaksudkan agar siswa dapat mengembangkan pengetahuan dan kemampuannya secara utuh. Dari berbagai mata pelajaran tersebut, PPKn merupakan salah satu mata pelajaran yang sering muncul dalam kegiatan pembelajaran untuk mengembangkan nilai, sikap dan kepribadian yang sesuai dengan Pancasila, UUD 1945, cinta tanah air, dan berwawasan kebangsaan.

Memadukan mata pelajaran dengan memperhatikan kompetensi dasar dari masing-masing mata pelajaran yang berkaitan tentunya memerlukan acuan atau tolak ukur untuk penilaiannya.Penilaian dalam kurikulum 2013 mencakup penilain sikap, pengetahuan, dan keterampilan yang dinyatakan sesuai rumusan kompetensi ini sebagai berikut. A) Kompetensi Inti-1 (KI-1) untuk kompetensi inti sikap spiritual. B) 
Kompetensi Inti-2 (KI-2) untuk kompetensi inti sikap sosial. C) Kompetensi Inti-3 (KI-3) untuk kompetensi inti pengetahuan. D) Kompetensi Inti-4 (KI-4) untuk kompetensi inti keterampilan.

Kompetensi inti pengetahuan sering dipergunakan sebagai acuan ketercapain suatu tujuan dalam proses pembelajaran. Karena kompetensi inti pengetahuan berkaitan dengan kemampuan kognitif siswa yang meliputi kemampuan mengetahui, memahami, menerapkan, menganalisis, dan mengevaluasi pengetahuan faktual, pengetahuan konseptual, pengetahuan prosedural, dan pengetahuan metakognitif dari suatu mata pelajaran.

Ketercapaian pengetahuan haruslah didukung dengan proses pembelajaran yang bervariasi. Variasi pembelajaran yang dilakukan oleh guru berupa penggunaan metode, model ataupun penggunaan media dalam proses pembelajaran. Penerapan variasi dalam pembelajaran belum dapat terlaksana di lapangan dengan baik. Informasi yang diperoleh pada tanggal 10-13 Januari 2018 dari seluruh guru kelas IV di Gugus I Kecamatan Gianyar, disampaikan bahwa saat sedang menjelaskan materi pembelajaran khususnya pembelajaran PPKn, perhatian siswa masih belum sepenuhnya terfokus ke pembelajaran karena masih belum optimalnya penggunaan variasi selama proses pembelajaran dan dapat mempengaruhi kontribusi siswa dalam proses pembelajaran. Pembelajaran monoton yang diterapkan selama proses pembelajaran di kelas akan mempengaruhi interaksi dua arah antara guru dan siswa selama proses pembelajran berlangsung.

Permasalahan sederhana yang belum banyak mendapat perhatian tersebut dapat diatasi dengan menerapkan variasi dalam proses pembelajaran yang berupa penerapan model pembelajaran. Model pembelajaran dalam kurikulum 2013 sangat bervariasi, salah satunya adalah model pembelajaran Open Ended yang memberikan permasalahn terbuka dengan beragam solusi.Sependapat dengan hal tersebut disampaikan oleh Lestari dan Mokhammad (2017:41) "Open-Ended adalah suatu pendekatan pembelajaran dengan menyajikan suatu permasalahan yang memiliki lebih dari satu jawaban dan atau metode penyelesaian (masalah terbuka)". Pemberian masalah terbuka atau open ended dapat membuat siswa lebih aktif dan dapat menyampaikan idenya, termotivasi dalam diri untuk menjelaskan dan mendapat pengalaman untuk menyelesaikan suatu permasalahan. Model pembelajaran yang diterapkan juga dapat dipadukan dengan menggunakan penilaian untuk menambah pemahaman siswa terhadap materi pembelajaran. Pada penelitian ini model pembelajaran akan dibasiskan dengan penilaian autentik berupa penilaian proyek untuk mengaplikasikan pemahaman siswa melalui sebuah tugas dengan jangka waktu tertentu. Pengaplikasian ini akan mampu mengembangkan kemampuan pemahaman siswa terhadap materi pembelajaran karena siswa akan mengaplikasikan pemahaman yang dimilikinya untuk diterapkan dalam kehidupan nyata. Selain itu disampaikan juga oleh Kunandar (2015) bahwa penilain proyek memiliki kelebihan seperti kebebasan mengemukakan ide, guru dan siswa lebih kreatif, tumbuhnya kemandirian dan tanggungjawab terhadap tugas yang diberikan, dan mempermudah penyampaian materi pembelajaran.

Penerapan variasi pembelajaran model Open Ended yang dibasiskan dengan penilaian proyek dapat mengembangkan pemahaman siswa terhadap materi pembelajaran dengan pemberian masalah terbuka yang memiliki banyak solusi penyelesainnya. Pemahaman yang didapat dari permasalahan terbuka tersebut akan diaplikasikan kedalam sebuah tugas dengan jangka waktu tertentu untuk menambah pemahaman siswa.

Sesuai dengan uraian tersebut secara teoritis penerapan model pembelajaran Open Ended berbasis penilaian proyek berpengaruh terhadap kompetensi pengetahuan siswa yang dalam penelitian ini memfokuskan pada kompetensi pengetahuan PPKn. Adapun tujuan dari penelitian ini untuk mengetahui perbedaan signifikan kompetensi pengetahuan PPKn kelompok siswa yang dibelajarkan melalui model pembelajaran Open Ended berbasis penilaian proyek dengan kelompok siswa dibelajarkan 
secara konvensional pada kelas IV SD Gugus I Kecamatan Gianyar Tahun Pelajaran 2017/2018.

\section{METODE PENELITIAN}

Penelitian ini termasuk dalam rancangan eksperimen kuasi (QuasiExperimental) yang dalam pemilihan untuk subjek penelitian tidak selalu dapat dilakukan secara random (individual random) dan penelitipun tidak dapat memilih subjek sesuai rancangannya (Setyosari, 2015). Rancangan eksperimen semu yang dipakai dalam penelitian ini menggunakan rancangan kelompok Non-ekuivalen. Karena hal tersebut, peneliti harus mengambil subjek penelitian sesuai dengan kelompok atau kelas yang ada sesuai kebijakan sekolah karena tidak memungkinkan untuk membuat kelompok atau kelas baru dalam suatu sekolah. Penelitian ini terditi dari 3 tahapan yaitu tahap persiapan eksperimen, tahap pelaksanaan eksperimen, dan tahap akhir eksperimen.

Populasi pada penelitian ini adalah seluruh siswa Kelas IV SD Gugus I Kecamatan Gianyar Tahun Pelajaran 2017/2018 yang berjumlah 434 siswa. Penentukan sampel menggunakan teknik sampling yaitu Probability Sampling,teknik sampling yang termasuk dalam probability sampling ialah Simple Random Sampling. Teknik sampel ini dalam penarikan sampel menggunakan teknik random atau mengacak yang akan memberikan kesempatan kepada semua populasi untuk dapat diipilih menjadi sampel. Hasil pengundian diperoleh Kelas IVA SD Negeri 1 Gianyar dan Kelas IV Melati SD Negeri 2 Gianyar, selanjutnya diuji kesetaraannya dengan menggunakan uji-t yang terlebih dahulu data dari kedua kelompok sudah memenuhi uji prasyarat normalitas sebaran data dan mohogenitas varians.

Berdasarkan hasil uji-t yang dilakukan diperoleh bahwa kedua kelompok tersebut setara dengan hasil analisis menunjukkan nilai $\mathrm{t}_{\text {hitung }}=1,169$, untuk $\mathrm{dk}=\left(\mathrm{n}_{1}+\mathrm{n}_{2}\right)-2=$ 78 dengan taraf signifikan 5\% diperoleh $t_{\text {tabel }}$ $=1,991$ sehingga $t_{\text {hitung }}<t_{\text {tabel }}$ maka $H_{0}$ diterima sehingga kedua kelompok setara.
Selanjutnya diundi untuk menentukan kelompok kelas eksperimen dan kelompok kelas kontrol, sehingga didapat Kelas IV Melati SD Negeri 2 Gianyar sebagai kelompok kelas eksperimen dan Kelas IVA SD Negeri 1 Gianyar sebagai kelompok kelas kontrol.

Pengaruh dalam suatu penelitian semata-mata karena perlakuan yang diberikan, hal ini berkaitan dengan validitas penelitian.Validitas penelitian dapat dibedakan menjadi dua, yaitu validitas internal dan eksternal sebagai berikut.

Validitas internl menyangkut tingkat kualitas ketepatan pengendalian aspek fisikpsikologis pelaksanaan penelitian dan penggunaan istrumen dalam penelitian (Dantes, 2017). Validitas internal yang dapat dikendalikan pada penelitian ini seperti karakteristik subjek dengan melakukan pengujian kesetaraan dari kelompok kelas yang nantinya menjadi sampel penelitian. Ancaman testingdiatasi dengan menganalisis skor perolehan yaitu nilai pretest dan posttest dari subjek penelitian yang dinormalisasikan (gain score normalization). Perubahan yang terjadi karena pengaruh waktu dan bukan dari perlakuakn berkaitan dengan maturaty, ancaman ini dapat dikendalikan dengan menggunakan kelompok sampel yang memiliki tingkat perkembangan sama yaitu tingkat kelas IV, serta pelaksanaan penelitian tidak dilakukan dalam jangka waktu yang lama. Terdapat juga ancaman dari Implementer Effect yang dapat dikendalikan dengan kemampun implementer yang keduanya sama lulusan Sarjana Pendidikan Guru Sekolah Dasar, serta proses pembelajaran pada sampel penelitian memiliki kesamaan buku tema, kompetensi dasar, indikator serta instrument pengumpulan data yang dipergunakan.Selain Validitas internal terdapat juga validitas eksternal yang perlu dikendalikan, pengendalian dapat dilakukan dengan pembatasan penelitian hanya pada kelas IV SD Gugus I Kecamatan Gianyar dan penarikan sampel dengan teknik random sampling agar hasil penelitian dapat digeneralisasikan pada populasi.

Data yang dikumpulkan pada penelitain ini adalah nilai kompetensi 
pengetahuan PPKn siswa.Metode pengumpulan data merupakan teknik atau cara dalam suatu penelitian yang dipergunakan oleh peneliti untuk mengumpulkan data sesuai dengan keperluan penelitian. Penelitian ini menggunakan metode tes, metode tes diartikan sebagai sebuah cara pengumpulan data dengan pemberian tugas kepada seseorang atau kelompok yang harus dikerjakan. Tes yang dipergunakan berupa tes objektif pilihan ganda biasa dan telah diuji validitas, daya pembeda, indeks kesukaran dan reliabilitas sehingga didapatkan 30 butir soal yang valid.

Setelah data dikumpulkan kemudian dicari terlebih dahulu gain skor dinormalisasi dari nilai pretest dan posttest sampel penelitian dengan rumus sebagai berikut.

(Sumber: Dantes, 2017:126)

$$
G S n=\frac{\text { Gain Skor }}{\text { Skor max }- \text { Skor pretest }}
$$

Keterangan :

GSn : Gainskor yang dinormalisasi

Gain Skor : Selisih skor pretest dan skor posttest

Skor Max : Skor maksimal ideal

Skor pretest : Skor pretest

Analisis data yang sudah didapat menggunakan analisis statistik deskriptif dan statistik inferensial.Statistik deskriptif menurut Sudaryono (2017:348) merupakan "statistik yang digunakan untuk menganalisis data dengan menggunakan cara mendeskripsikan atau menggambarkan data yang telah terkumpul sebagaimana adanya tanpa bermaksud membuat kesimpulan yang berlaku umum atau generalisasi”. Penyajian data dalam penelitian ini dengan pendekatan Penilaian Acuan Normatif (PAN) yang menggunakan perhitungan statistik Mean $(M)$ dan Standar Deviasi (s).Statistik inferensial ialah teknik statistik untuk analisis data sampel yang hasilnya berlaku terhadap populasi (Sudaryono, 2017).Sebelum dilakukan uji hipotesis dengan statistik inferensial menggunakan statistik parametrik, data yang dianalisis harus mememnuhi beberapa prasyarat yaitu uji normalitas sebaran data dan uji homogenitas varians.

Uji normalitas sebaran data menggunakan teknik Kolmogorov-smirnov untuk mengetahui apakah data sampel yang diambil berdistribusi normal atau data tersebut signifikan dengan populasi dimana sampel tersebut diambil.Kriteria dalam pengujian untuk teknik kolmogorov- smirnovyaitu apabila nilai $\mathrm{A}_{1}$ maksimum $\leq$ nilai tabel kolmogorov-smirnov pada taraf signifikansi $5 \%$ dengan $\mathrm{n}=$ jumlah sampel, maka data berdistribusi normal. Sedangkan untuk uji homogenitas varians dipergunakan untuk mengetahui sama atau homogennya nilai secara statistik. Salah satu uji homogenitas varians yang dapat dipergunakan adalah uji Fisher $(F)$.Kriteria dalam pengujian ini adalah: jika $F$ hitung $<F$ tabel, maka kedua kelompok homogen dengan $\mathrm{F}$ tabel untuk taraf signifikan 5\% $\mathrm{dk}_{\text {pembilang }}=\mathrm{n}_{\mathrm{a}}-1$ dan $\mathrm{dk}_{\text {penyebut }}=\mathrm{n}_{\mathrm{b}}-1$. Untuk $\mathrm{n}_{\mathrm{a}}=$ banyaknya data kelompok varians terbesar (pembilang) dan $\mathrm{n}_{\mathrm{b}}=$ banyaknya data kelompok varians terkecil (penyebut) (Supardi, 2016).

Setelah uji prasayarat dipenuhi maka uji hipotesis dengan menggunakan statistik parametrik dapat dilakukan. Pengujian hipotesis penelitian menggunakan uji perbedaan mean (Uji-t). Karena anggota sampel penelitian ini $\mathrm{n}_{1} \neq \mathrm{n}_{2}$ dan varians homogen, maka digunakan uji-t dengan rumus polled varians. Kriteria pengujian hipotesis yang dipergunakan pada taraf signifikan $5 \%$ dengan $\mathrm{dk}=\mathrm{n}_{1}+\mathrm{n}_{2}-2$ adalah jika harga $t_{\text {hitung }} \leq t_{\text {tabel }}$, maka $\mathrm{H}_{\mathrm{o}}$ diterima dan $\mathrm{H}_{\mathrm{a}}$ ditolak, dan jika harga $\mathrm{t}_{\text {hitung }}>\mathrm{t}_{\text {tabel }}$ maka $\mathrm{H}_{\mathrm{o}}$ ditolak dan $\mathrm{H}_{\mathrm{a}}$ diterima. 


\section{HASIL DAN PEMBAHASAN}

Data yang diperoleh dalam penelitian ini dikelompokkan menjadi dua yaitu : (1) data kompetensi pengetahuan PPKn Kelas IV Melati SD Negeri 2 Gianyar sebagai kelompok kelas eksperimen, (2) data kompetensi pengetahuan PPKn Kelas IVA SD Negeri 1 Gianyar sebagai kelompok kelas kontrol.

Mendeskripsikan data gain skor kelompok kelas eksperimen dilakukan dengan mencari Mean dan Standar Deviasi dengan hasil sebagai berikut.

Tabel 1. Penghitungan Data Gain Skor Dinormalisasi Kelompok Kelas Eksperimen

\begin{tabular}{ll}
\hline Mean & 0,366 \\
\hline Standar Deviasi & 0,202 \\
\hline
\end{tabular}

Hasil perhitungan mean dan standar deviasi dipergunakan untuk konversi tabel PAN Skala 5 sebagai berikut.

Tabel 2. Pedoman Konversi PAN dengan Skala 5

\begin{tabular}{ll}
\hline Hasil & Kategori \\
\hline $0,669 \rightarrow 0,972$ & Sangat Baik \\
\hline $0,467 \rightarrow<0,669$ & Baik \\
\hline $0,265 \rightarrow<0,467$ & Cukup Baik \\
\hline $0,063 \rightarrow<0,265$ & Tidak Baik \\
\hline$(-0,24) \rightarrow<0,063$ & Sangat Tidak Baik \\
\hline
\end{tabular}

Selanjutnya distribusi frekuensi tunggal kompetensi pengetahuan PPKn siswa dapat disajikan dengan grafik histogram seperti pada gambar 1 berikut.

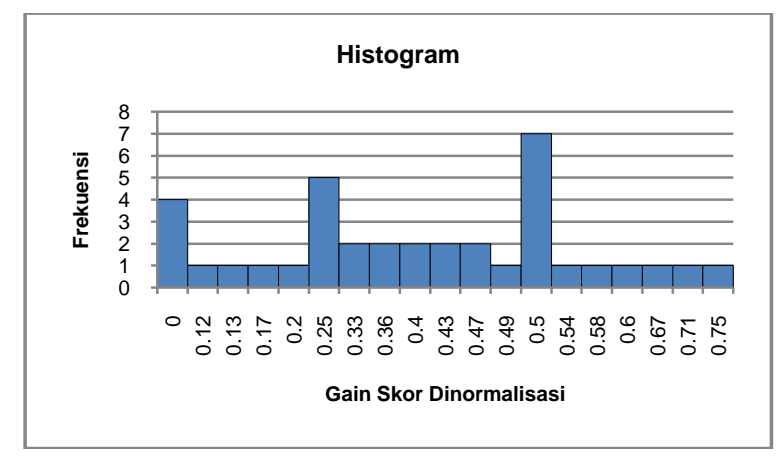

Gambar 1. Histogram Gain Skor Dinormalisasi Kompetensi Pengetahuan PPKn Siswa Kelas IV Melati

Berdasarkan pedoman konversi PAN dengan Skala 5 dan grafik histogram gain skor dinormalisasi kompetensi pengetahuan PPKn siswa kelas IV Melati dapat dijelaskan bahwa terdapat 4 orang siswa termasuk kategori sangat tidak baik, 9 orang kategori tidak baik, 8 orang pada kategori cukup baik, 12 siswa termasuk kategori baik dan 3 orang termasuk kategori sangat baik. Berdasarkan hasil tersebut juga dapat dicermati nilai gain skor dinormalisasi siswa kelas IV Melati yang berada dibawah rata-rata sebanyak 15 orang dan yang mencapai rata-rata sebanyak 21 orang.

Mendeskripsikan data gain skor kelompok kelas kontrol juga samadengan mencari Mean dan Standar Deviasi dengan hasil sebagai berikut. 
Tabel 3. Deskripsi Data Gain Skor Kelompok Kelas Kontrol

\begin{tabular}{ll}
\hline Mean & 0,263 \\
\hline Standar Deviasi & 0,166 \\
\hline
\end{tabular}

Hasil perhitungan mean dan standar deviasi dipergunakan untuk konversi tabel PAN Skala 5 sebagai berikut.

Tabel 4. Pedoman Konversi PAN dengan Skala 5

\begin{tabular}{l|l}
\hline Hasil & Kategori \\
\hline $0,512 \rightarrow 0,761$ & Sangat Baik \\
\hline $0,346 \rightarrow<0,512$ & Baik \\
\hline $0,18 \rightarrow<0,346$ & Cukup Baik \\
\hline $0,014 \rightarrow<0,18$ & Tidak Baik \\
\hline$(-0,235) \rightarrow<0,014$ & Sangat Tidak Baik \\
\hline
\end{tabular}

Selanjutnya distribusi frekuensi gain skor dinormalisasi kompetensi pengetahuan PPKn siswa dapat disajikan grafik histogram pada gambar 2 berikut.

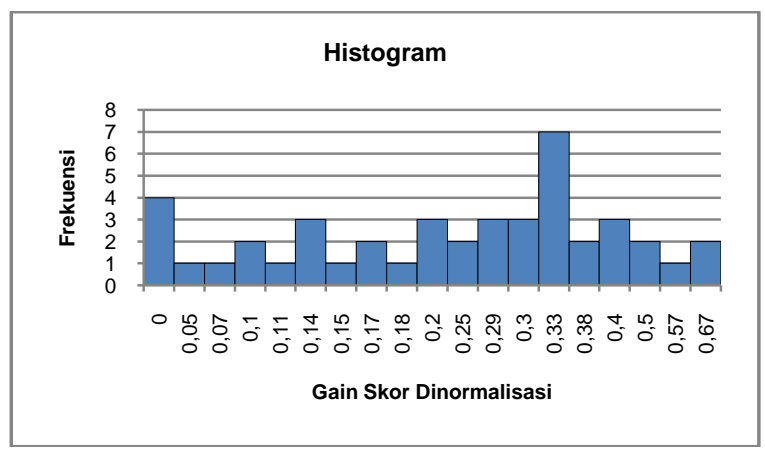

Gambar 2. Histogram Gain Skor Dinormalisasi Kompetensi Pengetahuan PPKn Siswa Kelas IV A

Berdasarkan pedoman konversi PAN dengan Skala 5 dan grafik histogram gain skor dinormalisasi kompetensi pengetahuan PPKn siswa kelompok kelas kontrol dapat dijelaskan bahwa terdapat 4 orang siswa termasuk kategori sangat tidak baik, 10 orang kategori tidak baik, 18 orang pada kategori cukup baik, 7 siswa termasuk kategori baik dan 3 orang termasuk kategori sangat baik. Berdasarkan hasil tersebut juga dapat dicermati nilai gain skor dinormalisasi siswa kelas IV A yang berada dibawah ratarata sebanyak 21 orang dan yang mencapai rata-rata sebanyak 23 orang.

Uji prasyarat dalam penelitian dilakukan sebagai syarat dipergunakanya statistik parametrik seperti penguji hipotesis dengan menggunakan uji-t.Uji prasyarat tersebut, terdiri dari uji normalitas sebaran data yang dapat menggunakan teknik kolmogorov-smirnov dan uji homogenitas varians dengan menggunakan uji fisher.

Kriteria dalam pengujian untuk teknik kolmogorov-smirnovyaitu apabila nilai $\mathrm{A}_{1}$ maksimum $\leq$ nilai tabel kolmogorov-smirnov pada taraf signifikansi $5 \%$ dengan $\mathrm{n}=$ jumlah sampel, maka data berdistribusi normal.

Hasil uji normalitas kelompok kelas eksperimen mendapatkan nilai $\mathrm{A}_{1}$ maksimum $=0,088 \mathrm{dan}$ kemudian dibandingkan dengan nilai tabel kolmogorov-smirnov pada taraf signifikansi $5 \%$ untuk $\mathrm{n}=36$ diperoleh nilai 0,221 , sehingga nilai $\mathrm{A}_{1}$ maksimum < nilai tabel kolmogorov-smirnov yang artinya data kelompok kelas eksperimen berdistribusi normal. Untuk kelompok kelas kontrol diperoleh nilai $\mathrm{A}_{1}$ maksimum $=0,116$ dan kemudian dibandingkan dengan nilai tabel 
kolmogorov-smirnov pada taraf signifikan 5 $\%$ untuk $\mathrm{n}=44$ dicari dengan rumus $\frac{1,36}{\sqrt{N}}$ dan diperoleh nilai tabel 0,205 (Cahyono,2015), sehingga nilai $\mathrm{A}_{1}$ maksimum < nilai tabel kolmogorov-smirnov yang artinya data kelompok kelas kontrol berdistribusi normal.

Setelah data kedua kelompok kelas berdistribusi normal, dilanjutkan dengan uji homogenitas varians data kedua kelompok kelas.Tujuannya uji homogenitas ini untuk mengetahui apakah data kedua kelompok kelas homogen atau tidak.Hasil pengujian menunjukkan bahwa diperoleh nilai $\mathrm{F}_{\text {hitung }}=$ 1,46. Adapun nilai $F_{\text {tabel }}$ pada taraf signifikansi $5 \%$ dengan $\mathrm{dk}_{\text {pembilang }}=35$ dan $\mathrm{dk}_{\text {penyebut }}=43$ adalah 1,70 , sehingga perbandingan $F_{\text {hitung }}<F_{\text {tabel }}$ yaitu 1,46< 1,70. Sesuai dengan pengujian tersebut data kelompok kelas eksperimen dan kelompok kelas kontrol homogen.

Hasil uji prasyarat menunjukkan bahwa data kelompok kelas eksperimen maupun kontrol berdistribusi normal dan memiliki varians yang homogen, karena data yang diperoleh telah memenuhi uji prayarat maka statistik parametrik dengan uji t untuk uji hipotesis dapat dipergunakan. Adapun hipotesis yang diuji pada penelitian ini yaitu tidak terdapat perbedaan yang signifikan kompetensi pengetahuan PPKn antara kelompok siswa yang dibelajarkan dengan model pembelajaran Open Ended berbasis penilaian proyek dengan kelompok siswa dibelajarkan dengan pembelajaran konvensional pada kelas IV SD Gugus I Kecamatan Gianyar Tahun Pelajaran 2017/2018.

Hasil analisis uji-t diperoleh $t_{\text {hitung }}=$ 2,494. Sedangkan nilai $t_{\text {tabel }}$ pada taraf signifikansi $5 \%$ dengan $\mathrm{dk}=\mathrm{n}_{1}+\mathrm{n}_{2}-2=36+44$ $2=78$ menunjukkan nilai $t_{\text {tabel }}$ sebesar 1,991 . Sehingga diperoleh hasil analisis nilai $t_{\text {hitung }}$ $=2,494>t_{\text {tabel }}=1,991$ maka $H_{0}$ ditolak dan $\mathrm{H}_{\mathrm{a}}$ diterima. Hal ini menunjukkan terdapat perbedaan yang signifikan kompetensi pengetahuan PPKn antara kelompok siswa yang dibelajarkan dengan model pembelajaran Open Ended berbasis penilaian proyek dengan kelompok siswa dibelajarkan dengan pembelajaran konvensional pada kelas IV SD Gugus I Kecamatan Gianyar Tahun Pelajaran 2017/2018.
Hasil uji hipotesis yang telah diperoleh menunjukkan nilai $t_{\text {hitung }}=2,494$, pada taraf signifikansi $5 \%$ dengan $\mathrm{dk}=78$ diperoleh nilai $t_{\text {tabel }}$ sebesar 1,991. Jika dibandingkan $t_{\text {hitung }}>t_{\text {tabel }}$ maka dari itu hipotesis nol $\left(\mathrm{H}_{0}\right)$ ditolak dan hipotesis alternatif $\left(\mathrm{H}_{\mathrm{a}}\right)$ yang menyatakan terdapat perbedaan yang signifikan kompetensi pengetahuan PPKn antara kelompok siswa yang dibelajarkan dengan model pembelajaran Open Ended berbasis penilaian proyek dengan kelompok siswa dibelajarkan dengan pembelajaran konvensional pada kelas IV SD Gugus I Kecamatan Gianyar Tahun Pelajaran 2017/2018 diterima.

Perbedaan signifikan kompetensi pengetahuan PPKn antara kelompok siswa yang dibelajarkan dengan model pembelajaran Open Ended berbasis penilaian proyek dengan kelompok siswa dibelajarkan dengan pembelajaran konvensional dapat dilihat dari perbedaan hasil analisis statistik deskriptif kedua kelompok tersebut. Secara deskriptif rata-rata gain skor dinormalisasi kompetensi pengetahuan PPKn siswa kelompok eksperimen $\bar{X}=0,366$ lebih dari rata-rata gain skor dinormalisasi kompetensi pengetahuan PPKn kelompok kontrol $\bar{X}=$ 0,263 .

Analisis statistik nilai pretest siswa diperoleh bahwa kedua kelompok kelas setara, setelah diberikan perlakukan berupa penerapan model pembelajaran open ended berbasis penilaian proyek pada kelas eksperimen diperoleh perbedaan gain skor dinormalisasi kompetensi pengetahuan PPKn siswa. Nilai gain skor dinormalisasi kompetensi pengetahuan PPKn siswa pada kelompok kelas eksperimen lebih tinggi dari gain skor dinormalisasi kompetensi pengetahuan PPKn siswa pada kelompok kelas kontrol. Perbedaan tersebut terlihat dari rata-rata gain skor dinormalisasi kompetensi pengetahuan PPKn siswa yang diberikan perlakuan model pembelajaran open ended berbasis penilaian proyek lebih tinggi dibandingkan dengan rata-rata gain skor dinormalisasi kompetensi pengetahuan PPKn siswa yang dibelajarkan dengan pembelajaran konvensional.

Pada kelompok eksperimen, kegiatan pembelajaran pada muatan materi PPKn 
menerapkan model pembelajaran open ended berbasis penilaian proyek dapat mengaktifkan siswa selama proses pembelajaran berlangsung. Aktifnya proses pembelajaran tersebut dikarenakan penerapan model pembelajaran open ended berbasis penilaian proyek memberikan sebuah permasalahan dengan berbagai solusi penyelesaian agar siswa mampu untuk menyelesaikan permasalahan sesuai dengan kemampuan yang dimilikinya dan mengembangkan pemahaman siswa dari pada sekedar mengetahui. Pemahaman yang diperoleh oleh siswa dapat diaplikasikan kedalam sebuah tugas dengan jangka waktu tertentu yang berkaitan dengan pemahaman, pengaplikasian, penyelidikan, serta penginformasian. Tugas tersebut diinvestigasi atau dianalisis oleh siswa mulai dari perencanaan, pengumpulan data, pengolahan dan hasil. Berdasarkan hal tersebut, pembelajaran dengan model pembelajaran open ended berbasis penilaian proyek dalam pembelajarannya akan mengembangkan pemahaman, pengalaman penyelesaian masalah, mampu menyampaikan pendapat lewat pemberian permasalahan terbuka dan pengaplikasian pemahaman siswa lewat sebuah tugas untuk menambah pemahaman siswa. Pembelajaran kelompok kelas kontrol dalam menyampaikan materi kepada siswa hanya diselingi dengan sedikit tanya jawab kemudian diikuti dengan pemberian tugas secara individu. Dengan pembelajaran seperti ini, siswa belum optimal mempunyai kesempatan untuk mengembangkan kemampuan berpikir, kesempatan untuk mengajukan ide yang dimiliki, serta memecahkan masalah yang ditemui.Pembelajaran seperti ini, membuat siswa merasa bosan dan jenuh sehingga sulit untuk memahami materi pelajaran. Dengan demikian, perbedaan hasil kompetensi pengetahuan PPKn siswa dapat terlihat dari keunggulan penerapan model pembelajaran open ended berbasis penilaian proyek, nilai rata-rata gain skor dinormalisasi, dan hasil uji hipotesis dari kelompok kelas eksperimen dan kelompok kelas kontrol.

Hasil penelitian ini memiliki persamaan dengan penelitian sebelumnya yang relevan dan mendukung hasil penelitian
relevan.Penelitian ini mendukung hasil penelitian yang dilakukan oleh Lestari (2017) dengan analisis menunjukkan bahwa terdapat perbedaan yang signifikan kompetensi pengetahuan IPA antara kelompok eksperimen dengan kelompok kontrol siswa kelas V SD Gugus IV Jendral Sudirman Denpasar Selatan tahun ajaran 2016/2017. Hal tersebut dibuktikan dengan hasil $t_{\text {hitung }}=3,497>t_{\text {tabel }}(\alpha=0,05,76)=$ 2,000 .

\section{SIMPULAN DAN SARAN}

Berdasarkan hasil penelitian dan pembahasan dari analisis data dapat disimpulkan bahwa nilai gain skor kompetensi pengetahuan PPKn kelompok siswa yang dibelajarkan dengan model pembelajaran open ended berbasis penilain proyek dikonversikan pada tabel PAN Skala 5 terdapat 4 siswa kategori sangat tidak baik, 9 siswa kategori tidak baik, 8 siswa kategori cukup baik, 12 siswa kategori baik dan 3 siswa kategori sangat baik serta gain skor dinormalisasi yang berada dibawah rata-rata sebanyak 15 orang dan yang mencapai ratarata sebanyak 21 orang. tersamuk dalam kategori cukup baik. Untuk gain skor kompetensi pengetahuan PPKn kelompok siswa yang dibelajarkan dengan pembelajaran konvensional dikonversikan juga pada tabel PAN Skala 5 terdapat 4 siswa kategori sangat tidak baik, 10 siswa kategori tidak baik, 18 siswa kategori cukup baik, 7 siswa kategori baik dan 3 siswa kategori sangat baik serta gain skor dinormalisasi yang berada dibawah rata-rata sebanyak 21 orang dan yang mencapai ratarata sebanyak 23 orang.

Hasil analisis uji hipotesis menyatakan bahwa terdapat perbedaan yang signifikan nilai gain skor dinormalisasi dari kedua kelompok kelas. Hal ini dibuktikan dengan analisis uji-t diperoleh $t_{\text {hitung }}=2,494$ sedangkan pada taraf signifikan 5\% dengan $\mathrm{dk}=78$ diperoleh nilai $\mathrm{t}_{\text {tabel }}=1,991$. Karena $\mathrm{t}_{\text {hitung }}=2,494>\mathrm{t}_{\text {tabel }}=1,991$ maka $\mathrm{H}_{0}$ ditolak dan hipotesis alternatif $\left(\mathrm{H}_{\mathrm{a}}\right)$ yang menyatakan terdapat perbedaan yang signifikan kompetensi pengetahuan PPKn antara kelompok siswa yang dibelajarkan 
melalui model pembelajaran Open Ended berbasis penilaian proyek dengan kelompok siswa dibelajarkan secara konvensional pada kelas IV SD Gugus I Kecamatan Gianyar Tahun Pelajaran 2017/2018 diterima. Dari hasil analisis tersebut dapat disimpulkan bahwa model pembelajaran Open Ended berbasis penilaian proyek berpengaruh terhadap kompetensi pengetahuan PPKn siswa kelas IV SD Gugus I Kecamatan Gianyar Tahun Pelajaran 2017/2018.

Berdasarkan hasil penelitian ini, dapat diajukan beberapa saran sebagai tindak lanjut dari penelitian ini.Saran ini diajukan kepada berbagai pihak yang terkait dengan manfaat hasil penelitian.

Guru diharapkan dapat memvariasikan proses pembelajaran yang dilakukan di kelas dengan menerapkan model pembelajaran atau penggunaan media dan peniaian autentik seperti model pembelajaran open ended yang dibasiskan dengan penilaian proyek agak siswa mampu mengembangkan kemampuan dan pemahamannya.

Pihak sekolah tempat penelitian diharapkan mampu untuk memanfaatkan hasil penelitian sebagai acuan dalam mengembangkan variasi dalam proses pembelajaran dikelas dengan menyediakan vasilitas dan pemberian pelatihan tentang variasi dalam proses pembelajaran seperti penerapan model pembelajaran atau penilaian autentik.

Peneliti bidang sejenis yang memiliki kesamaan baik variabel bebas, varibel terikat ataupun melanjutkan penelitian ini agar hasil penelitian ini agar nantinya dapat menjadi penelitian yang relevan.

\section{DAFTAR RUJUKAN}

Cahyono, Tri. 2015. Statistik Uji Normalitas. Purwoketo: Yayasan Sanitarian Banyumas.

Dantes, Nyoman. 2017. Desain Eksperimen dan Analisis Data. Depok: Rajawali Pers.

Trianto. 2015. Mendesain Model Pembelajaran Inovatif, Progresif, dan Kontekstual: Konsep Landasan, dan Implementasi pada Kurikulum 2013 (Kurikulum Tematik Integratif/TKI). Jakarta: Prenadamedia Group.

Kunandar.2015. Penilaian Autentik (Penilaian Hasil Belajar Peserta Didik Berdasarkan Kurikulum 2013) Edisi Revisi. Jakarta: PT Raja Grafindo Persada.

Lestari, Kadek Dita. 2017. Pengaruh Model Pembelajaran Open Ended Berbasis Keterampilan Menjelaskan terhadap Kompetensi Pengetahuan IPA. Journal of Education Technology. Universitas Pendidikan Ganesha, Volume 1, Nomor 3. Tersedia pada http://ejournal.undiksha.ac.id/index.p $\underline{\mathrm{hp}}$ (diakses tanggal 12 Januari 2018 pada pukul 18:16).

Lestari, Karunia Eka dan Mokhammad Ridwan Yudhanegara. 2017. Penelitian Pendidikan Matematika (Panduan Prkatis Menyusun Skripsi, Tesis dan Laporan Penelitian dengan Pendekatan Kuantitatif, Kualitatif dan Kombinasi Disertasi dengan Model Pembelajaran dan Kemampuan Matematis). Bandung: PT Refika Aditama.

Sagala, Syaiful. 2013. Konsep dan Makna Pembelajaran. Bandung: Alfabeta

Setyosari, H. Punaji. 2015. Metode Penelitian Pendidikan dan Pengembangan Edisi Keempat. Jakarta: Prenadamedia Group.

Sudaryono. 2017. Metodologi Penelitian. Jakarta: PT RajaGrafindo Persada.

Supardi U.S., 2016. Aplikasi Statistik dalam Penelitian Edisi Revisi Konsep Statistika yang Lebih Komprehensif. Jakarta Selatan: Change Publication

Syah, Muhibbin. 2010. Psikologi Pendidikan. Bandung: PT Remaja Rosdakarya. 
Undang-undang Republik Indonesia No. 20

Tahun 2003 tentang Sistem

Pendidikan Nasional. 